Cin Şeker, Z. ve Çobanoğlu, D. (2015) Türkçe öğretmeni adaylarının günlük dilde sık kullanılan kelimelerin doğru yazımını bilme düzeyleri. Ana Dili Eğitimi Dergisi, 3(3), 51-63.

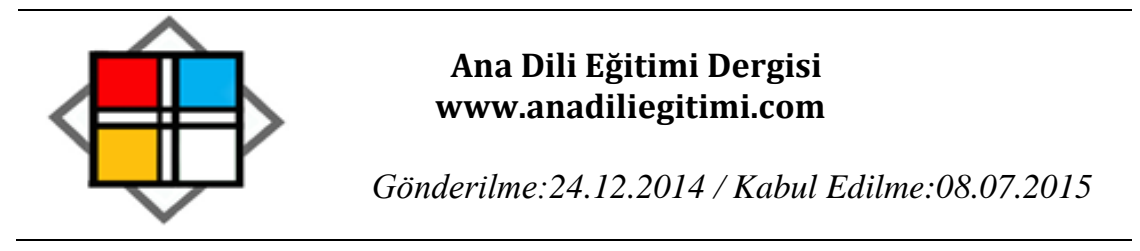

\title{
Türkçe Öğretmeni Adaylarının Günlük Dilde Sık Kullanılan Kelimelerin Doğru Yazımını Bilme Düzeyleri
}

\author{
Zeynep CIN ŞEKER* \\ Deniz ÇOBANOĞLU**
}

\begin{abstract}
Öz
Bu çalışmada, Türkçe öğretmen adaylarının günlük yazılı ve sözlü dilde sık kullanıldığı düşünülen kelimelerin doğru yazımlarını bilme düzeylerinin tespit edilmesi amaçlanmıştır. Bu doğrultuda Atatürk Üniversitesi Kazım Karabekir Eğitim Fakültesi Türkçe Eğitim Bölümünde 1. Sınıfta öğrenim görmekte olan 104 öğrenciye araştırmacılar tarafından hazırlanan kelime testi uygulanmıştır. Araştırmanın amacı doğrultusunda günlük yazılı ve sözlü dilde sık kullanıldığı düşünülen 96 kelime seçilmiş ve bu kelimelerin $48^{\prime}$ inin yazımı değiştirilerek kelime testi oluşturulmuştur. Türkçe öğretmeni adaylarından yazımının doğru olduğunu düşündükleri kelimeyi doğru, yanlış olduğunu düşündükleri kelimeyi yanlış kabul ederek doğru yazımını göstermeleri istenmiştir. Kelime testleri, oluşturulan rubrik doğrultusunda değerlendirilmiştir. Yapılan kelime testi sonucunda Türkçe öğretmeni adaylarının günlük hayatta yanlış yazımı ile sıklıkla karşılaştıkları kelimelerin yanlış yazımlarını doğru olarak kabul ettikleri tespit edilmiştir. Genelde dili kullanan tüm bireylerin özelde ise Türkçe öğretmeni adaylarının dili kullanma bilgi ve bilincine sahip olmaları gerektiği düşünülmektedir.
\end{abstract}

Anahtar sözcükler: Türkçe öğretmeni adayları, yazım, kelime.

\section{Knowledge Levels of Preservice Teachers of Turkish in Terms of Correct Script of Word Frequently Used in Daily Language}

\begin{abstract}
In this study, it is aimed to determine the level of Turkish Language Teachers in terms of knowing the correct spelling of the most frequently used words in daily life. In this manner, the vocabulary test prepared by the researchers was applied to 104 freshmen chosen from Turkish Language Teaching Department in Kazım Karabekir Faculty of Education at Atatürk University. As considering the aim of this study, 96 vocabulary items that are frequently used in daily life were determined for the vocabulary test and the test was used after the spelling of 48 words had been changed by the researchers. The participants were wanted to tick the correctly spelled words and if there was a wrong spelling, then they were wanted to correct them. The vocabulary test was evaluated with the help of a rubric that was specifically designed for this study. As a result of the study, it was seen the participants thought that some vocabulary items were spelled correctly even if they were wrong because they generally come across the wrong spelled version of those vocabulary items in their daily life. It is thought that all people, especially freshmen Turkish Language Teachers, should have the knowledge and awareness of the correct linguistics constructs.
\end{abstract}

Keywords: Freshmen Turkish Language Teachers, spelling, word.

\footnotetext{
* Arş. Gör., Atatürk Üniversitesi, Kazım Karabekir Eğitim Fakültesi, Türkçe Eğitimi Bölümü, Erzurum. e-posta: zeynep.seker@atauni.edu.tr

** Arş. Gör., Atatürk Üniversitesi, Kazım Karabekir Eğitim Fakültesi, Türkçe Eğitimi Bölümü, Erzurum. e-posta: dnz2424@hotmail.com
} 


\section{Giriş}

Birey dünyaya geldiği ilk andan itibaren dille çevrili bir ortamda yaşamaya başlar. Kazanılan ilk dil becerisi dinlemedir. Konuşma ise dinleyerek kazanılır. Dinleme ve konuşma becerisinin kazanımı okul eğitimi gerektirmez. Ancak okuma ve yazma becerisinin kazanımı okul eğitimiyle başlar. Bir dili tam anlamıyla öğrenmek o dilde anlatılanları dinleyip anlamayı, okuma yapabilmeyi, o dilin imkânlarını kullanarak konuşmayı ve kurallarına uygun şekilde yazabilmeyi gerektirir. Coşkun (2009: 53-54)'a göre "Yazma becerisinin kazanılması dinleme, konuşma ve okuma becerilerinden sonra gerçekleşir. Okuma ve yazma ise kişinin çoğunlukla formal eğitim yoluyla kazandığı dil becerileridir. Okuma ve yazma becerileri ayrı ayrı düşünüldüğünde, okuma becerisinin, yazma becerisinin içinde bulunması gerektiği ortaya çıkar. Çünkü okuma bilmeyen kimsenin yazmayı bilmesi de mümkün değildir. Bu bakımdan bir yazının önce okunması sonra yazılması öğretilir". Bireyin yazma becerisini edinebilmesi için öncelikle okuma becerisini edinmesi gerekmektedir.

Dilin en önemli işlevlerinden biri bildirişimdir. Özcan (2003: 15)'a göre bildirişim, “Bir gönderici tarafından, öte yandaki bir alıcı üzerinde belli bir etki yaratmak amacı ile adına 'gösterge' denilen, anlam yüklü birimlerden yararlanarak, karşı tarafa belirli bir 'bildiri' ulaştırılması eylemi" dir. Genellikle konuşma iletişimi sağlayan en önemli dil becerisi olarak düşünülmektedir. Ancak insanlar arasında iletişimi sağlayan dil becerilerinden bir diğeri de yazmadır. Dinleme ve konuşma becerisini doğumundan itibaren zamanla edinen birey, okulla birlikte okuma ve yazma becerisini sistemli olarak kazanarak dört temel dil becerisini geliştirmeye başlar. Çok yönlü ve karmaşık bir eylem olan yazma becerisi, diğer dil becerilerini de kapsayan zihinsel bir süreçtir. Bu bağlamda dil becerilerinin birbirleri ile ilişkili olduğunu söylemek mümkündür. Yazabilmek için dinleme, konuşma ve okuma becerilerinin gelişmiş olması gerekmekte ve yazmanın da diğer dil becerilerinin gelişimine katkıda bulunacağı düşünülmektedir. Dinleme, okuma ve konuşma isteği gibi yazma isteği de insanda bulunan doğal bir eğilimdir ve bir süreç gerektirir.

Insana ait olan dil yetisi doğuştandır. Chomsky, dili evrensel edinç ve özel edinç olarak iki bölümde ele alır. "Evrensel edinç doğuştan gelir; özel edinç ise sonradan öğrenilir. Birincisi ikincinin öğrenilme koşuludur. İkincisi birincinin uygulama alanıdır. Edim ise, edincin konuşucular tarafından dilin kullanımı sırasında gerçekleştirilmesidir. Edinç sonsuz sayıda doğru tümce üreten devimsel bir yetenektir. Edim, bu yeteneğin gerçekleşmesidir" (Kıran, 2010: 164- 165). Yazma becerisi edinç ve edimin ortak ürünü olarak ortaya çıkar. İnsanın düşünce dünyasında var olanların yazı diline aktarılmasıyla yazma becerisi eylem olarak gerçekleşir.

Vardar (2002: 221-222)’a göre, "Yazı, dilin sesli göstergelerini karşılamayı amaçlayan, görüntüsel ögelerden ya da yazaçlardan oluşan göstergeler dizgesi. Yazım ise bir dili belli kurallar 
uyarında yazma, o dildeki sözcükleri yazıda gösterme biçimi” dir. Göstergeler dizgesi olan yazının, yazma eyleminin gerçekleştirileceği dilin yazım kurallarına uyması gerekir. Karadağ ve Maden (2013: 266) yazmayı, "Aktarılmak istenen anlamların harf adı verilen sembollerle kodlanmasıdır. Kodlama, üzerinde uzlaşılmış ortak kod ve sembollerle gerçekleşir" şeklinde ifade etmişlerdir. Bir yazıda aktarılmak istenen anlamların karşı tarafa doğru bir şekilde iletilmesinde yerinde sözcük kullanımı ve kullanılan sözcüklerin doğru yazılması önemlidir "Dil ve yazı birbirinden ayrı iki gösterge dizgesidir. Yazının biricik varlık nedeni dili göstermektir" (Saussure, 1998: 56).

Özbay (2011)'a göre standart dil, konuşma dilinden ve ağız özelliklerinden çok çabuk etkilendiği için imla kurallarına intiyaç duyulmuştur. "Bir dilin belli kurallarla yazıya geçirilmesine imla denir" (TDK, 2005: 2155). Yazma da ilk olarak yazım kurallarına uyarak gerçekleştirilir. Bülbül (2000: 11-12) yazılı anlatımda imla kurallarının önemini "Sözlü ve yazılı anlatımın temel malzemesi dildir. Dilin yapı taşları ise sözcüklerdir. İşte bunun içindir ki, anlatımı başarılı yapan unsurlardan biri, imlâ kurallarına uyulmasıdır. Bu kuralları gereği kadar bilmedikçe, düzenli bir metin yazmaya imkân yoktur. İmla yanlışlıkları genelde bilmemekten ve gerekli özeni göstermemekten kaynaklanmaktadır. Yanlışıklardan kurtulmak için dil bilgisi kurallarını da doğru öğrenecek, bunlara uyacak, sözcüklerin yazılışlarını öğrenecek, böylece başarılı yazma alışkanlığı kazanacağız" şekilde belirtmiştir.

Tabak (1998), çok sık rastlanan imla hatalarının nedenlerini üç ayrı şekilde ele almıştır:

“1)Zaman zaman yetkili/yetkisiz kişi veya kurumlarca imlâmızın kurallarının değiştirilmesinin; pek çok insanda dilimizin imlasında kararlılık olmadığı ve bu sebeple de herkesin istediği gibi konuşup yazacağı kanaatinin doğuşuna sebep olması

2)Örgün ve yaygın eğitim kurumlarındaki bazı sorumluların da 1. maddedeki anlayışla hareket edip imlamı üzerinde ciddiyetle durmamaları, dolayısıyla imlamızın öğretilmesindeki yetersizliğin yaygınlaşması

3)Öğrenilen imlayla ilgili kuralların bilgi düzeyinde kalıp uygulamaya intikal etmemesi. Bunun sonucu olarak; yazılı, sözlü/görüntülü iletişim araçlarında kullanılan Türkçenin, âdeta kuralları olmayan/herkesin kendi bildiğince kural koyup uygulayacağı bir dil haline getirilmesi" (Akt. Ağca, 2006: 81).

Günlük dilde sıklıkla kullanılan kelimelerin doğru yazııması için imla öğretimine önem vermek gerekmektedir. "Imla öğretimi, daha önce de belirtildiği gibi, yazma becerilerinin geliştirilmesinde önemli bir yere sahiptir. Öğrencilerin standart Türkçenin kurallarına hâkim olması ve bu becerilerini yazılı anlatımlarına yansıtmaları, öncelikle üzerinde durulması gereken noktalardan biridir" (Özbay, 2011: 181). Öğrencilerin yazılı anlatım becerileri başarılı bir imla öğretimi ile gelişecektir, bu 
gelişmeye paralel olarak öğrencilerin günlük dilde sıklıkla yanlış yazımı ile kullandıkları kelimelerin doğru yazımlarını öğrenecekleri düşünülmektedir.

“Düşüncenin taşıyıcısı değişik anlam tabakalarındaki dil göstergeleridir. Dil göstergeleri bütünü içinde sözcükler önemli yer tutar. Herhangi bir konuda konuşabilmek ve yazabilmek için sözcüklerin yerinde ve anlamına uygun kullanılması, doğru yazılmaları önem taşımaktadır" (Aktaş ve Gündüz, 2013: 187). Yazılı anlatımda seçilen sözcüğün, anlam olarak bütüne uygunluğunun yanında dilin kuralları doğrultusunda hatasız olarak yazılması gerekmektedir. Her öğrenci anlamsal boyutta ve estetik açıdan anlamlı ve güzel yazılar yazamaz. Öğrencilerin aynı konu ile ilgili olarak yazacakları metinler birbirlerinden farklı olacaktır. Bu durum öğrencilerin sözcük dağarcığına göre değişiklik gösterir. İlköğretim ve ortaöğretimi bitiren her öğrenci anlamını bildiği, yazılı anlatımlarında kullandığı sözcüklerin doğru yazılışlarına da hâkim olmalıdır. Etkili yazma bir ölçüde yeteneğe bağııdır. Ancak sözcükleri dilin yazım kurallarına uygun olarak doğru yazmak öğrenme ile ilgili olup eksiksiz olarak kazanılabilir. Dil eğitiminin hedeflerinden biri de budur. Bu bağlamda anlamsal ve estetik boyuta etkili yazı yazma veya temel yazılı anlatım becerisine sahip olan bireylerin ortak paydası yazılı anlatımlarında kullandıkları sözcüklerin doğru yazımını bilmeleri olmalıdır. Okulda dil eğitimi alan birey, yazım kurallarını öğrenerek yazma becerisi kazanır. Yazma becerisinin uygulama kısmı bilinenlerin, öğrenilenlerin harekete geçirilmesi işlemidir.

Illköğretim Türkçe Dersi Öğretim Programı́nda da yazılı anlatımın ne olduğu ve bunun için gerekli olan yazma becerisinin amaçları belirtilmiştir. Temel dil becerilerinin kazandırılmaya ve geliştirilmeye çalışıldığı programda bu amaçlar şu şekilde yer almıştır: "Yazııı anlatım, bireyin kendini doğru ve amacına uygun olarak ifade etmesinde ve iletişim kurmasında en etkili araçlardan biridir. Türkçe Öğretim Programı'nda yazma becerisinin geliştirilmesiyle; öğrencilerin duygu, düşünce, hayal, tasarı ve izlenimlerini dilin imkânlarından yararlanarak ve yazılı anlatım kurallarına uygun şekilde anlatmaları, yazmayı kendini ifade etmede bir alışkanlığa dönüştürmeleri ve yazma yeteneği olanların bu becerilerini geliştirmeleri amaçlanmaktadır" (MEB, 2005: 7).

Ortaöğretim Dil ve Anlatım Dersi Öğretim Programı́nda ise dilin yazılı ve sözlü kullanımı ile ilgili ifadelere yer verilmiştir. "Dil ve Anlatım dersinde, konuşulan ve yazılan dilin; anlamı, sesi, görünüşü, çağrışım değeri ve kurallarıyla bir sistem olduğu, bu sistemdeki ögelerin kullanım esnasında yeni değerler ve anlamlar kazandığı, her düzeydeki dil göstergesi ve dil birliklerinin şekil ve anlam olmak üzere iki yönü bulunduğu ancak bunları birbirinden ayırmanın imkânsız olduğu gibi hususlar temel hareket noktası durumundadır. Programın hareket noktası da ilköğretimi bitiren öğrencilerin, dili kullanma becerisi kazanarak zamanın intiyaçlarına cevap verebilecek aydın kişiler durumuna gelebilmelerini sağlamaktır. Bu derste öğrencilerin kazandıkları dil becerileri ile kendilerini her 
düzeyde sözlü ve yazılı olarak iyi, doğru ve güzel ifade etmeleri her türlü Türkçe metni doğru anlayıp yorumlayabilme alışkanlığı kazanmaları hedeflenmiştir" (MEB, 2011: 1-2).

Belirlenen hedefler doğrultusunda ilk ve ortaöğretimi tamamlayarak lisans eğitimine başlayan Türkçe öğretmeni adaylarından yazılı anlatım açısından beklenen, etkili yazılı anlatım becerisi kazanarak kendilerini ifade edebilmeleri ve yazılı anlatımı alışkanlık haline getirebilmeleridir. Bu bağlamda öğretmen adaylarının, sözcük seçimi kadar sözcüklerin doğru yazımlarını bilmeleri de önemlidir. Çünkü bir sözcüğün anlamını bilmek ve onu yerinde kullanmak o sözcüğün yazım kurallarına uygun yazılma gerekliliğini ortadan kaldırmaz. Özellikle Türkçe öğretimi gerçekleştirecek olan öğretmen adaylarının sözcükleri doğru yazımla kullanmaları son derece önemlidir.

Okullarda Türkçe öğretimini gerçekleştirecek olan Türkçe öğretmenleri dili kullanma becerileriyle öğrencilerine örnek olmaları gerekmektedir. Bu bağlamda Türkçe öğretmeni adaylarının yazılı anlatım becerilerinin de gelişmiş olması, yazılı anlatımlarında kullandıkları kelimelerin sadece anlam bakımından değil şekil olarak da doğru olması önemlidir. Gelişen teknolojinin insanların sosyal hayatları üzerinde bıraktığı etki, değişen yaşam standartları toplumun büyük bir bölümü gibi Türkçe öğretmeni adaylarının da dil becerilerini olumsuz etkilemektedir. Internette kullanılan sanal dil, mağaza ve dükkân isimleri, televizyon yayınları vs. gibi etkenler bireylerin sözlü ve yazılı dil kullanımlarını etkilemekte, bilinmeyen sözcük ve kuralların yanlış öğrenilmesine veya bilinen yanlışların pekişmesine neden olmaktadır. Sözcüklerin doğru yazımının öğrenilebileceği güvenilir, çabuk ulaşılabilir kaynak yazım kılavuzu ve sözlüklerdir. Yanlış bilinen sözcüklerin doğrusunu öğrenme isteğinin, merakının olmaması bu kaynakları kullanma alışkanlığının önündeki en büyük engellerdendir. Türkçe öğretmeni adaylarında dili doğru kullanma bilinci oluşmalı, adaylar sözcüklerin doğru yazımını öğrenebilecekleri kaynakları kullanma alışkanlığı edinmiş olmalıdır.

Yukarıda dikkat çekilen nedenler Türkçe öğretmeni adaylarını da etkilemekte, sözcükleri doğru yazma bilgi ve bilinci kazanmalarına engel olmaktadır. Çünkü sözcüklerin yazımında yapılan yanlışlar genellikle sözcüğün yanlış yazımı doğru bilindiği için yapılmaktadır. Bu nedenle geleceğin Türkçe öğretmenlerinin konu ile ilgili bilgi ve bilinç eksikliklerini gidermeleri için öncelikle durum tespiti yapılması gerekmektedir. Bu çalışmada da Türkçe öğretmen adaylarının günlük yazılı ve sözlü dilde sık kullanıldığı düşünülen kelimelerin doğru yazımlarını bilme düzeylerinin tespit edilmesi amaçlanmıştır.

\section{Amaç}

Bu çalışmada da Türkçe öğretmen adaylarının günlük yazılı ve sözlü dilde sık kullanıldığı düşünülen kelimelerin doğru yazımlarını bilme düzeylerinin tespit edilmesi amaçlanmıştır. Bu amaca ulaşmak için aşağıdaki sorulara cevap aranacaktır: 
1. Öğrencilerin testte verilen kelimelerin yazımlarını doğru bilme oranları nedir?

2. Öğrencilerin testte yazımı yanlış verilen kelimeleri yanlış kabul edip doğru yazımını yanlış bilme oranları nedir?

3. Öğrencilerin testte yazımı doğru verilen kelimenin yazımını yanlış bilme oranları nedir?

4. Öğrencilerin testte yanlış yazımı verilen kelimelerin doğru yazımını bilme oranları nedir?

\section{Yöntem}

Türkçe öğretmeni adaylarının günlük dilde sıkça kullanılan kelimelerin doğru yazımını bilme düzeylerini tespit etmeyi amaçlayan çalışma, tarama modelinde betimsel bir araştırmadır.

\section{Evren ve Örneklem}

Araştırmanın evrenini Türkiye'deki üniversitelerde Türkçe eğitimi bölümünde öğrenim gören 1. sınıf Türkçe öğretmeni adayları oluşturmaktadır. Çalışmanın örneklemi kolay ulaşılabilir örneklem yoluyla seçilen Atatürk Üniversitesi Kazım Karabekir Eğitim Fakültesi Türkçe Eğitimi Bölümü’nde 1. Sınıfta öğrenim gören 104 öğrenci ile oluşturulmuş ve çalışma sınırlandırılmıştır.

\section{Veri Toplama Aracı}

Veri toplama aracı olarak günlük yazılı ve sözlü dilde kullanılan ve yazımı sıklıkla karıştıııldığı düşünülen 100 kelimeden oluşan çalışma formu kullanılmıştır. Çalışma formundaki kelimelerden 50'sinin doğru yazımı, 50'sinin ise genellikle doğru olduğu düşünülen yanlış yazımına yer verilmiştir. Öğrencilerden yazımının doğru olduğunu düşündükleri kelimenin yanına (v), yazımının yanlış olduğunu düşündükleri kelimenin yanına $(\mathrm{x})$ işareti koyarak kelimenin doğru yazımını yazmaları istenmiştir.

\section{Verilerin Analizi}

Öğrencilere uygulanan kelime çalışmalarını değerlendirebilmek için uygun rubrik oluşturulmuştur. Testte doğru yazımına yer verilen kelimeye doğru, yanlış yazımına yer verilen kelimeye yanlış denilerek doğrusunun yazılmasına (4), yanlış yazımı verilen kelimeye yanlış denilerek kelimenin doğru yazımının da yanlış yazıımasına (3), doğru yazımına yer verilen kelimeye yanlış denilmesine (2), yanlış yazımı verilen kelimeye doğru denilmesine (1) ve boş bırakılan kelimeye (0) değerlendirmesi yapılmıştır. Bu puanların yüzde ve frekans değerleri çıkarılarak öğrencilerin kelimelerin doğru yazımını bilme oranları elde edilmiştir. 


\section{Bulgular ve Yorum}

Araştırmada elde edilen bulguların yüzde ve frekans değerleri tabloda yer almaktadır:

Tablo: Araştırma Grubundaki Öğrencilerin Testte Yer Alan Kelimelerin Doğru Yazımını Bilme Yüzdeleri

\begin{tabular}{|c|c|c|c|c|c|c|c|c|c|c|c|c|c|}
\hline & & & & $f$ & & & Toplam & & & $\%$ & & & Toplam \\
\hline & & 0 & 1 & 2 & 3 & 4 & 104 & 0 & 1 & 2 & 3 & 4 & 100 \\
\hline 1. & Antrenman & 15 & 0 & 28 & 0 & 61 & 104 & 14.4 & 0 & 26 & 0 & 58.6 & 100 \\
\hline 2. & İspat & 6 & 0 & 10 & 0 & 88 & 104 & 5.7 & 0 & 9.1 & 0 & 84 & 100 \\
\hline 3. & Öge & 2 & 62 & 0 & 0 & 40 & 104 & 1.9 & 59.6 & 0 & 0 & 38.4 & 100 \\
\hline 4. & Alerji & 0 & 11 & 2 & 1 & 90 & 104 & 0 & 10.5 & 0 & 0.96 & 86.5 & 100 \\
\hline 5. & Figür & 3 & 0 & 0 & 0 & 101 & 104 & 2.8 & 0 & 0 & 0 & 97.1 & 100 \\
\hline 6. & Kolonya & 2 & 0 & 10 & 0 & 92 & 104 & 1.9 & 0 & 9.6 & 0 & 88.4 & 100 \\
\hline 7. & Kurdele & 0 & 68 & 0 & 15 & 21 & 104 & 0 & 65.3 & 0 & 14.4 & 20.1 & 100 \\
\hline 8. & Şoför & 3 & 17 & 0 & 2 & 82 & 104 & 2.8 & 16.3 & 0 & 1.92 & 78.8 & 100 \\
\hline 9. & Kılavuz & 3 & 7 & 13 & 0 & 81 & 104 & 2.8 & 6.7 & 12.5 & 0 & 77.8 & 100 \\
\hline 10. & Daire & 1 & 0 & 0 & 0 & 103 & 104 & 0.96 & 0 & 0 & 0 & 99.03 & 100 \\
\hline 11. & Cip & 5 & 0 & 51 & 0 & 48 & 104 & 4.8 & 0 & 49.03 & 0 & 46.1 & 100 \\
\hline 12. & Aşçı & 1 & 17 & 0 & 3 & 83 & 104 & 0.96 & 16.3 & 0 & 2.8 & 79.8 & 100 \\
\hline 13. & Unvan & 1 & 72 & 0 & 0 & 31 & 104 & 0.96 & 69.2 & 0 & 0 & 29.8 & 100 \\
\hline 14. & Sünger & 0 & 21 & 0 & 0 & 83 & 104 & 0 & 20.1 & 0 & 0 & 79.8 & 100 \\
\hline 15. & Psikiyatri & 4 & 0 & 18 & 0 & 82 & 104 & 3.8 & 0 & 17.3 & 0 & 78.8 & 100 \\
\hline 16. & Stajyer & 1 & 0 & 32 & 0 & 71 & 104 & 0.96 & 0 & 30.7 & 0 & 68.2 & 100 \\
\hline 17. & Tıraş & 4 & 0 & 17 & 0 & 78 & 104 & 3.8 & 0 & 16.3 & 0 & 75 & 100 \\
\hline 18. & Meyve & 1 & 23 & 0 & 0 & 80 & 104 & 0.96 & 22.1 & 0 & 0 & 76.9 & 100 \\
\hline 19. & Abajur & 5 & 1 & 6 & 0 & 92 & 104 & 4.8 & 0.96 & 5.7 & 0 & 88.4 & 100 \\
\hline 20. & Çikolata & 1 & 2 & 0 & 0 & 102 & 104 & 0.96 & 1.9 & 0 & 0 & 98.07 & 100 \\
\hline 21. & Maydanoz & 2 & 39 & 0 & 1 & 62 & 104 & 1.9 & 37.5 & 0 & 0.96 & 59.6 & 100 \\
\hline 22. & Profesör & 4 & 0 & 17 & 0 & 83 & 104 & 3.8 & 0 & 16.3 & 0 & 79.8 & 100 \\
\hline 23. & Minibüs & 3 & 57 & 0 & 6 & 38 & 104 & 2.8 & 54.8 & 0 & 5.7 & 36.5 & 100 \\
\hline 24. & Dershane & 0 & 0 & 18 & 0 & 86 & 104 & 0 & 0 & 17.3 & 0 & 82.6 & 100 \\
\hline 25. & Ziraat & 1 & 0 & 4 & 0 & 99 & 104 & 0.96 & 0 & 3.8 & 0 & 95.1 & 100 \\
\hline 26. & Çeyiz & 1 & 17 & 0 & 1 & 85 & 104 & 0.96 & 16.3 & 0 & 0.96 & 81.7 & 100 \\
\hline 27. & Eşkıya & 3 & 73 & 0 & 0 & 28 & 104 & 2.8 & 70.1 & 0 & 0 & 26.9 & 100 \\
\hline 28. & Şofben & 6 & 0 & 28 & 0 & 70 & 104 & 5.7 & 0 & 26.9 & 0 & 67.3 & 100 \\
\hline 29. & Değişik & 0 & 2 & 0 & 0 & 102 & 104 & 0 & 1.9 & 0 & 0 & 98.07 & 100 \\
\hline 30. & Şarj & 3 & 0 & 4 & 0 & 97 & 104 & 2.8 & 0 & 3.8 & 0 & 93.2 & 100 \\
\hline
\end{tabular}




\begin{tabular}{|c|c|c|c|c|c|c|c|c|c|c|c|c|c|}
\hline 31. & Röportaj & 1 & 1 & 22 & 0 & 80 & 104 & 0.96 & 0.96 & 21.1 & 0 & 76.9 & 100 \\
\hline 32. & Rençper & 5 & 91 & 0 & 8 & 0 & 104 & 4.8 & 87.5 & 0 & 7.6 & 0 & 100 \\
\hline 33. & Kavanoz & 1 & 21 & 0 & 3 & 78 & 104 & 0.96 & 20.1 & 0 & 2.8 & 75 & 100 \\
\hline 34. & Dinozor & 0 & 0 & 46 & 0 & 58 & 104 & 0 & 0 & 44.2 & 0 & 55.7 & 100 \\
\hline 35. & Palyaço & 3 & 50 & 0 & 4 & 47 & 104 & 2.8 & 48 & 0 & 3.8 & 45.1 & 100 \\
\hline 36. & İade & 1 & 0 & 5 & 0 & 98 & 104 & 0.96 & 0 & 4.8 & 0 & 94.2 & 100 \\
\hline 37. & Erozyon & 2 & 33 & 0 & 1 & 68 & 104 & 1.9 & 31.7 & 0 & 0.96 & 65.3 & 100 \\
\hline 38. & Silahşor & 2 & 99 & 0 & 0 & 3 & 104 & 1.9 & 95.1 & 0 & 0 & 2.8 & 100 \\
\hline 39. & Egzoz & 2 & 0 & 16 & 0 & 86 & 104 & 1.9 & 0 & 15.3 & 0 & 82.6 & 100 \\
\hline 40. & Laboratuvar & 2 & 28 & 0 & 2 & 72 & 104 & 1.9 & 28.9 & 0 & 1.9 & 69.2 & 100 \\
\hline 41. & Randevu & 2 & 28 & 0 & 2 & 72 & 104 & 1.9 & 26.9 & 0 & 1.9 & 69.2 & 100 \\
\hline 42 & Zanaat & 2 & 0 & 7 & 0 & 95 & 104 & 1.9 & 0 & 6.7 & 0 & 91.3 & 100 \\
\hline 43. & Çünkü & 1 & 0 & 5 & 0 & 88 & 104 & 0.92 & 0 & 4.8 & 0 & 84.6 & 100 \\
\hline 44. & Sezaryen & 4 & 0 & 59 & 1 & 40 & 104 & 3.8 & 0 & 56.7 & 0.92 & 3.8 & 100 \\
\hline 45. & Kooperatif & 0 & 32 & 0 & 8 & 64 & 104 & 0 & 30.7 & 0 & 7.6 & 61.5 & 100 \\
\hline 46. & Kapüşon & 8 & 85 & 0 & 10 & 1 & 104 & 7.6 & 81.7 & 0 & 9.6 & 0.96 & 100 \\
\hline 47. & Postane & 3 & 0 & 20 & 0 & 81 & 104 & 2.8 & 0 & 19.2 & 0 & 77.8 & 100 \\
\hline 48. & Matbaa & 1 & 0 & 8 & 0 & 95 & 104 & 0.92 & 0 & 7.6 & 0 & 91.3 & 100 \\
\hline 49. & Mezhep & 0 & 24 & 0 & 4 & 76 & 104 & 0 & 23.07 & 0 & 3.8 & 73.07 & 100 \\
\hline 50. & Ünite & 0 & 4 & 0 & 1 & 99 & 104 & 0 & 3.8 & 0 & 0.96 & 95.1 & 100 \\
\hline 51. & Komodin & 8 & 0 & 50 & 0 & 46 & 104 & 7.6 & 0 & 48.07 & 0 & 44.2 & 100 \\
\hline 52. & Eşofman & 0 & 22 & 0 & 7 & 73 & 104 & 0 & 21.1 & 0 & 6.7 & 70.1 & 100 \\
\hline 53. & Çerkez & 2 & 8 & 0 & 0 & 94 & 104 & 1.9 & 7.6 & 0 & 0 & 90.3 & 100 \\
\hline 54. & Gardırop & 7 & 0 & 28 & 0 & 69 & 104 & 6.7 & 0 & 26.9 & 0 & 66.3 & 100 \\
\hline 55. & Kambur & 5 & 22 & 0 & 2 & 75 & 104 & 4.8 & 21.1 & 0 & 1.9 & 72.1 & 100 \\
\hline 56. & Pantolon & 2 & 11 & 0 & 2 & 79 & 104 & 1.9 & 10.5 & 0 & 1.9 & 75.9 & 100 \\
\hline 57. & Herkes & 1 & 0 & 9 & 0 & 93 & 104 & 0.96 & 0 & 8.6 & 0 & 89.4 & 100 \\
\hline 58. & Yakamoz & 2 & 16 & 0 & 0 & 86 & 104 & 1.9 & 15.3 & 0 & 0 & 82.6 & 100 \\
\hline 59. & Makine & 4 & 65 & 0 & 0 & 35 & 104 & 3.8 & 62.5 & 0 & 0 & 33.6 & 100 \\
\hline 60. & Bisküvi & 2 & 19 & 0 & 22 & 61 & 104 & 1.9 & 18.2 & 0 & 21.1 & 58.6 & 100 \\
\hline 61. & Fasulye & 2 & 0 & 18 & 0 & 84 & 104 & 1.9 & 0 & 17.3 & 0 & 80.7 & 100 \\
\hline 62. & Motosiklet & 5 & 79 & 0 & 0 & 20 & 104 & 4.8 & 75.9 & 0 & 0 & 19.2 & 100 \\
\hline 63. & Merhem & 1 & 19 & 0 & 2 & 82 & 104 & 0.96 & 18.2 & 0 & 1.9 & 78.8 & 100 \\
\hline 64. & Sürpriz & 2 & 0 & 21 & 0 & 81 & 104 & 1.9 & 0 & 20.1 & 0 & 77.8 & 100 \\
\hline 65. & illüzyon & 2 & 0 & 55 & 0 & 47 & 104 & 1.9 & 0 & 52.8 & 0 & 45.1 & 100 \\
\hline 66. & Enstitü & 2 & 0 & 18 & 0 & 83 & 104 & 1.9 & 0 & 17.3 & 0 & 79.8 & 100 \\
\hline 67. & Aferin & 2 & 16 & 0 & 7 & 79 & 104 & 1.9 & 15.3 & 0 & 6.7 & 75.9 & 100 \\
\hline
\end{tabular}




\begin{tabular}{|c|c|c|c|c|c|c|c|c|c|c|c|c|c|}
\hline 68. & Yeğen & 1 & 28 & 0 & 0 & 75 & 104 & 0.96 & 26.9 & 0 & 0 & 72.1 & 100 \\
\hline 69. & Profesyonel & 3 & 1 & 8 & 0 & 92 & 104 & 2.8 & 0.96 & 7.6 & 0 & 88.4 & 100 \\
\hline 70. & Kakao & 3 & 0 & 3 & 0 & 98 & 104 & 2.8 & 0 & 2.8 & 0 & 94.2 & 100 \\
\hline 71. & Acayip & 4 & 29 & 0 & 0 & 71 & 104 & 3.8 & 27.8 & 0 & 0 & 68.2 & 100 \\
\hline 72. & Lavabo & 1 & 18 & 0 & 1 & 84 & 104 & 0.96 & 17.3 & 0 & 0.96 & 80.7 & 100 \\
\hline 73. & Anneanne & 7 & 0 & 6 & 0 & 91 & 104 & 6.7 & 0 & 5.7 & 0 & 87.5 & 100 \\
\hline 74. & Menü & 2 & 38 & 0 & 0 & 64 & 104 & 1.9 & 36.5 & 0 & 0 & 61.5 & 100 \\
\hline 75. & Ağabey & 2 & 61 & 0 & 5 & 36 & 104 & 1.9 & 58.6 & 0 & 4.8 & 34.6 & 100 \\
\hline 76. & Faaliyet & 3 & 0 & 12 & 0 & 89 & 104 & 2.8 & 0 & 11.5 & 0 & 85.5 & 100 \\
\hline 77. & Kontör & 3 & 17 & 0 & 5 & 79 & 104 & 2.8 & 16.3 & 0 & 4.8 & 73.07 & 100 \\
\hline 78. & Deterjan & 0 & 43 & 0 & 0 & 61 & 104 & 0 & 41.3 & 0 & 0 & 58.6 & 100 \\
\hline 79. & Bijuteri & 7 & 0 & 28 & 0 & 69 & 104 & 6.7 & 0 & 26.9 & 0 & 66.3 & 100 \\
\hline 80. & İnisiyatif & 0 & 0 & 66 & 0 & 38 & 104 & 0 & 0 & 63.4 & 0 & 36.5 & 100 \\
\hline 81. & Koleksiyon & 4 & 54 & 0 & 0 & 46 & 104 & 3.8 & 51.9 & 0 & 0 & 44.2 & 100 \\
\hline 82. & Kapitülasyon & 0 & 26 & 0 & 39 & 38 & 104 & 0 & 25 & 0 & 37.5 & 36.5 & 100 \\
\hline 83. & Alüminyum & 3 & 0 & 16 & 0 & 85 & 104 & 2.88 & 0 & 15.3 & 0 & 81.7 & 100 \\
\hline 84. & İddia & 1 & 19 & 0 & 19 & 65 & 104 & 0.96 & 18.2 & 0 & 18.2 & 62.5 & 100 \\
\hline 85. & Karnabahar & 5 & 0 & 73 & 0 & 26 & 104 & 4.8 & 0 & 70.1 & 0 & 25 & 100 \\
\hline 86. & Afetzede & 4 & 0 & 18 & 0 & 82 & 104 & 3.8 & 0 & 17.3 & 0 & 78.8 & 100 \\
\hline 87. & Poğaça & 1 & 40 & 0 & 9 & 54 & 104 & 0.96 & 3.8 & 0 & 8.6 & 51.9 & 100 \\
\hline 88. & Yalnız & 0 & 16 & 0 & 0 & 88 & 104 & 0 & 15.3 & 0 & 0 & 84.6 & 100 \\
\hline 89. & Bağırsak & 0 & 0 & 3 & 0 & 101 & 104 & 0 & 0 & 2.8 & 0 & 97.1 & 100 \\
\hline 90. & Espri & 1 & 0 & 39 & 0 & 66 & 104 & 0.96 & 0 & 37.5 & 0 & 63.4 & 100 \\
\hline 91. & Sandviç & 2 & 0 & 21 & 0 & 81 & 104 & 1.9 & 0 & 20.1 & 0 & 77.8 & 100 \\
\hline 92. & Repertuvar & 5 & 0 & 46 & 0 & 52 & 104 & 4.8 & 0 & 44.2 & 0 & 50 & 100 \\
\hline 93. & Hafriyat & 3 & 83 & 0 & 2 & 13 & 104 & 2.8 & 79.8 & 0 & 1.92 & 12.5 & 100 \\
\hline 94. & Komiser & 4 & 10 & 0 & 0 & 90 & 104 & 3.8 & 9.6 & 0 & 0 & 86.5 & 100 \\
\hline 95. & Beynelmilel & 6 & 94 & 0 & 0 & 4 & 104 & 5.76 & 90.3 & 0 & 0 & 3.8 & 100 \\
\hline 96. & Herhalde & 2 & 0 & 10 & 0 & 92 & 104 & 1.9 & 0 & 9.6 & 0 & 88.4 & 100 \\
\hline
\end{tabular}

\section{Birinci Alt Probleme Ait Bulgular ve Yorum}

Tablo incelediğinde öğrencilerin doğru yazımını bildikleri kelimelerin oranı şöyledir: daire (\%99.03), değişik (\%98.07), çikolata (\%98), figür (\%97.1), ziraat (\%95.1), ünite (95.1), iade (\%94.2), kakao (\%94.2), şarj (\%93.2), zanaat (\%91.3), matbaa (\%91.3), Çerkez (\%90.3), herkes (\%89.4), herhalde, abajur, profesyonel, kolonya(\%88.4), anneanne (\%87.5) 
Çerkez ve ünite kelimeleri testte yanlış yazımlarıyla yer almıştır. Daire, değişik, çikolata, figür, ziraat, ünite, iade, kakao, şarj, zanaat, matbaa, Çerkez, herkes, herhalde, abajur, profesyonel, kolonya ve anneanne kelimeleri günlük hayatta sıklıkla kullanılan kelimelerdir. Bu kelimeler gazete, dergi, reklam panoları, afiş gibi basılı yayın ürünlerinde ve öğrencilerin sıklıkla kullandığı genel ağ ortamında yaygın şekilde kullanılan kelimeler olduğu için doğru yazımının öğrenciler tarafından bilindiği düşünülmektedir.

Öğrencilerin doğru yazımını en az bildikleri kelimeler ise şöyledir: Rençper (\%0), kapüşon (\%0.96), silahşor (\%2.8), beynelmilel (\%3.8), sezaryen (\%3.8), hafriyat (\%12.5), motosiklet (\%19.2), kurdele (\%20.1), karnabahar (\%25), eşkıya (\%26.9), unvan (\%29.8), makine (\%33.6), ağabey (\%34.6), inisiyatif, kapitülasyon, minibüs (\%36.5).

Öğrencilerin doğru olarak cevaplama oranının en düşük olduğu kelimeler genellikle yanlış yazımı verilen kelimelerdir. Bu kelimelerin yanlış yazımları testte şu şekilde yer almıştır: rençber, kapşon, silahşör, beynelminel, harfiyat, motorsiklet, kurdela, eşkiya, ünvan, makina, abi, kapitilasyon, minübüs. Bu bağlamda öğrencilerin yazımı yanlış verilen kelimelerin doğru yazımlarını bilmedikleri ve yanlış yazımlarını doğru olarak bildikleri tespit edilmiştir.

\section{Alt Probleme Ait Bulgular}

Tablo incelendiğine öğrencilerin, kelime testinde yazımı yanlış verilen bazı kelimeleri yanlış olarak işaretledikleri ancak kelimenin farklı bir yanlış yazımını doğru yazım olarak kabul ettikleri tespit edilmiştir. Öğrenciler tarafından bu şekilde cevaplanan kelimelerin ortalaması sırasıyla kapitülasyon (\%37.5), bisküvi (\%21.1), iddia (\%18.2), kurdele (\%14.4), kapüşon (\%9.6), poğaça (\%8.6), rençper, kooperatif (\%7.6), eşofman, aferin (\%6.7), minibüs (\%5.7), ağabey, kontör (\%4.8), mezhep, palyaçodur (\%3.8). Bu kelimelerin testte yer alan yanlış yazımları ise şöyledir: kapitilasyon, bisküvü, idda, kurdela, kapşon, poaça, rençber, koperatif, eşortman, aferim, minübüs, abi, kontür, meshep, palyanço.

Bisküvi kelimesinin yanlış yazımı testte bisküvü olarak yer almıştır. Kelimenin yazımının yanlış olduğuna karar veren ancak doğru yazımını da yanlış bilen öğrencilerin cevaplarından bazıları şöyledir: büsküvi, büskivü, bisküvü, biskivü, büskivi, biskivi, büsküvü. İddia kelimesinin yanlış yazımı testte idda şeklindedir. Öğrenciler bu kelimenin doğru yazımı ile ilgili şu cevapları vermişlerdir: iddaa, iddiaa, iddea, idaa. Kelimenin iddaa şeklindeki yazımının öğretmen adayları tarafından doğru kabul edilmesinin en önemli nedenlerinden biri gençlerin dikkatini çeken, zamanlarını ayırdıkları şans oyunu bayi tabelalarında iddia kelimesinin iddaa şeklindeki yazımına yer verilmiş olmasıdır. Bu durum mağaza ve dükkân isimlerinin insanların dili doğru kullanmaları üzerinde etkili olduğunun göstergesidir. 
Testte yanlış yazımı kurdela, poaça, kontür ve minübüs olarak verilen kelimelerin de sosyal yaşamda çeşitli yanlış yazımları kullanılmaktadır. Bu kelimeleri testte yanlış olarak işaretleyen öğrencilerin doğru olarak kabul ettikleri yanlış yazımlar ise şöyledir: kurdale, poğça, pohaça, puaça, pohça, kontor, kontur, köntör, minibus, münübüs, münibüs.

Öğrencilerin testte yazımı yanlış verilen diğer kelimelerin doğru olduğunu düşündükleri yazımları şöyledir:, kooparatif, komperatif, koaperatif, koparatit, afferim, ağferim, kapişon, kapşön, kapuşon, kapşun, sezaryan, amelyat, ameliyet, ağbi, âbi, kapütülasyon, kapitülâsyon, kapütilasyon, kapütülosyon, palaço, mesheb, mezheb, acayib, reçber, rejber.

\section{İkinci Alt Probleme Ait Bulgular ve Yorum}

Tablo incelendiğinde öğrencilerin, doğru yazımlarını yanlış yazım kabul ettikleri ortalaması en yüksek kelimeler, karnabahar (\%70.1), inisiyatif (\%63.4), sezaryen (\%56.7), illüzyon (\%52.8), cip (\%49.3), komodin (\%48.07), dinozor, repertuvar (\%44.2), espri (\%37.5), stajyer (\%30.7), şofben, gardırop, bijuteri (\%26.9), antrenman (\%26), röportaj (\%21.1), sürpriz, sandviç (\%20.1), postane (\%19.2), psikiyatri, dershane, fasulye, enstitü, afetzede (\%17.3), profesör, tıraş (\%16.3) şeklindedir.

Öğrenciler, yukarıda yer alan ve testte doğru yazımı verilen kelimelerin yazımını yanlış olarak kabul etmiş ve kelimeleri doğru olduğunu düşündükleri şekilde yazmışlardır. Öğrencilerin doğru olduğunu düşündükleri yanlış yazımlar ise şöyledir: karnıbahar, komidin, komedin, komudin, enstüti, enstütü, aliminyum, alaminyum, bijüteri, bujiteri, bujuteri, büjiteri, büjüteri, sandaviç, sandüviç, sandeviç, sandiviç, sandivinç, sezeryan, sezaryan, sezeryen, repertuar, reperatuvar, reportuar, röpertuar, dinazor, dinözor, ilüzyon, ilizyon, illizyon, dersane, postahane, posthane, süpriz, şohben, şofpen, stajer, fasülye, espiri, gardorop, gardrop, gardolap, gardrap, insiyatif, instiyatif, ropörtaj, röpörtaj, âfetzede, affetzede, pröfesör, proföser, profösör, profosör, profösor, pskiyatri, psikyatri, jip, jeep, antreman.

\section{Üçüncü Alt Probleme Ait Bulgular ve Yorum}

Tablo incelendiğinde öğrencilerin testte yanlış yazımı verilen bazı kelimeleri doğru olarak işaretledikleri görülmektedir. Bu kelimelerden ortalaması yüksek olanlar sırasıyla: silahşor (\%95.1), beynelmilel (\%90.3), rençper (\%87.5), kapüşon (\%81.7), hafriyat (\%79.8), motosiklet (\%75.9), eşkıya (\%70.1), unvan (\%69.2), kurdele (\%65.3), makine (\%62.5), öge (\%59.6), ağabey (\%58.6), minibüs (\%54.8),koleksiyon (\%51.9), palyaçodur (\%48).

Yukarıdaki kelimelerin testte yer alan yanlış yazımları şöyledir: silahşör, beynelminel, rençber, kapşon, harfiyat, motorsiklet, eşkiya, ünvan, kurdela, makina, öğe, abi, minübüs, kolleksiyon, palyanço. 


\section{Sonuç}

Uygulanan kelime testi ile Türkçe öğretmeni adaylarının kelimelerin doğru yazımlarını bilme durumları tespit edilmek istenmiştir. Yapılan kelime testi sonucunda Türkçe öğretmeni adaylarının günlük hayatta yanlış yazımı ile sıklıkla karşılaştıkları kelimelerin yanlış yazımlarını doğru olarak kabul ettikleri tespit edilmiştir. Kelimelerin günlük dilde yanlış yazımları ile kullanılmaları öğretmen adaylarının kelimelerin yanlış yazımlarını doğru yazım olarak kabul etmelerine neden olduğu düşünülmektedir. Gündüz ve Şimşek (2011: 106) de "Yazma yanlışlarının sebepleri çeşitlidir. Öğrenci yazma yanlışı yaptığı sözcükle ya ilk kez karşılaşmıştır ya yazııışını yanlış öğrenmiştir ya da öğrendiği sırada yazılışına dikkat etmemiştir" ifadeleri ile yazım yanlışlarının nedenlerini belirtmişlerdir.

Öğretmen adaylarının yabancı kökenli kelimeleri söylendiği gibi yazdıkları görülmektedir. Yabancı kökenli kelimelere günlük dilde yanlış ses ekleme ve çıkarmanın yapılması, kelimelerin bu şekilde yaygınlaşması yabancı kökenli kelimelerin yanlış yazımlarının doğru kabul edilmesine yol açmaktadır.

Testte yazımı yanlış olarak yer alan bazı kelimelerin öğretmen adayları tarafından doğru kabul edilmesinin muhtemel sebepleri arasında mağaza ve dükkân isimlerinin kelimelerin yanlış yazımları ile oluşturulması; genel ağ ortamında ve televizyonda kelimelerin doğru yazımlarını kullanmaya yönelik farkındalığın oluşmaması; dergi, gazete, el ilanları ve reklam panoları gibi basım yayın ürünlerinde kelimelerin doğru kullanımları hususunda titizlik gösterilmemesi yer almaktadır. Türkçeyi kullanan bireylerde yazım kılavuzu kullanma alışkanlığının olmaması kelimelerin doğru yazımlarının duyulduğu, görüldüğü veya telaffuz edildiği şekilde doğru kabul edilmesine neden olmaktadır. Beyreli, Çetindağ ve Celepoğlu (2011, s. 18), Türkçenin genel olarak yazıldığı gibi seslendirilen, seslendirildiği gibi yazılan bir dil olduğunu belirtmiş ve bu durumu ağabey biçiminde yazılan sözcüğün günlük dilde âbi biçiminde de söylenmekte olduğunu bundan başka geliyorum, tutacağız, sağlam, eğlence, secde vb. sözcüklerin ağızlarda ya da günlük konuşmada yazıldığı biçimden farklı seslendirilebildiğini ifade ederek örneklendirmişlerdir. Arı ve Evat (2010) çalışmalarında yazım ve telaffuzu karıştırılan sözcükler üzerinde durmuş, kelimelerin yanlış yazımı ve telaffuzunun kişiden kişiye aktarılarak ve iletişim araçlarında kullanılarak yaygınlaştığına dikkat çekmişlerdir. Bu şekilde yanlış dile yerleşmekte ve zamanla doğrunun yerini almaktadır. Çalışmalarııın sonucunda öğrencilerin yazım ve telaffuzunda sıkça yanlış yapılan kelimelerde sıkıntı yaşadıklarını belirlemişlerdir.

Dili kullanan bireylerin kelimelerin yanlış yazımlarıyla karşılaşabilecekleri ortamlar ve durumlar oldukça fazladır. Genelde Türkçeyi kullanan tüm bireylerin, özelde ise gelecek nesillerin dil bilincinin oluşmasına katkı sağlayacak Türkçe öğretmen adaylarının dili doğru kullanma bilgi ve 
becerisine sahip olmaları gerekir. Bu bağlamda Türkçe öğretmen adaylarının yazılı anlatımlarının dilin kurallarına uygun olması gerekmektedir. Türkçe öğretmen adaylarında sosyal hayatta birden fazla yazımı yer alan kelimelerin doğru yazımına ulaşma bilinci ve yazım kılavuzu kullanma alışkanlığı olmalıdır.

\section{Kaynakça}

Ağca, H. (2006). Yazııı anlatım. Ankara: Gündüz Eğitim ve Yayıncılık.

Akbayır, S. (2011). Nasıl yazabilirim?. Ankara: Pegem Akademi Yayınları.

Aktaş, Ş., Gündüz, O. (2013). Yazııı ve sözlü anlatım. Ankara: Akçağ Yayınları.

Arı, G. ve Evat, Y. (2011). Ortaöğretim mezunlarının yazım ve telaffuzunu karıştırdığı sözcükler. İ. Yazar (Ed.), III. Uluslararası Dünya Dili Türkçe Sempozyumu Bildiri Kitabı (ss. 78-87). İzmir: Dokuz Eylül Üniversitesi.

Başkan, Ö. (2003). Bildirişsim insan-dili ve ötesi. İstanbul: Multilingual Yabancı Dil Yayınları.

Beyreli L., Çetindağ, Z. ve Celepoğlu, A. (2011). Yazılı ve sözlü anlatım. Ankara: Pegem Akademi Yayınları.

Bülbül, A. R. (2000). Yazııı anlatım ve yazı türleri. Ankara: Nobel Yayınları.

Coşkun, E. (2009). Yazma eğitimi. A. Kırkılıç, .ve H. Akyol (Ed.), ilköğretimde Türkçe öğretimi (2.Baskı) (ss.49-91). Ankara: Pegem Akademi Yayınları.

Gündüz, O. ve Şimşek, T. (2011). Anlatma teknikleri 2 uygulamalı yazma eğitimi el kitabı. Ankara: Grafiker Yayınları.

Kantemir, E. (1995). Yazılı ve sözlü anlatım. Ankara: Engin Yayınları.

Karadağ, Ö. ve Maden, S. (2013). Yazma eğitimi: kuram, uygulama, ölçme ve değerlendirme. A. Güzel ve H. Karatay (Ed.), Türkçe öğretimi el kitabı (1. Baskı) (ss.265-301). Ankara: Pegem Akademi Yayınları.

Kavcar, C., Oğuzkan, F. ve Aksoy, Ö. (2011). Yazılı ve sözlü anlatım. Ankara: Anı Yayıncılık.

Kıran, Z. ve Eziler Kıran, A. (2010). Dilbilime giriş. Ankara: Seçkin Yayınları.

Millî Eğitim Bakanlığı. (2006). Illköğretim Türkçe dersi (6, 7, 8. sınıflar) öğretim programı. Ankara: Millî Eğitim Bakanlığı Yayınları.

Millî Eğitim Bakanlığı. (2011). Dil ve anlatım dersi 9, 10, 11 ve 12. Sınıflar öğretim programı. Ankara: Millî Eğitim Bakanlığı Yayınları.

Özbay, M ( 2011). Yazma eğitiminde noktalama ve imla. M. Özbay (Ed.), Yazma eğitimi (2.Baskı) (177-190). Ankara: Pegem Akademi Yayınları

Saussure, F. de. (1998). Genel dilbilim dersleri. İstanbul: Multilingual Yabancı Dil Yayınları.

TDK. (2005). Türkçe sözlük. Ankara: Türk Dil Kurumu Yayınları.

Vardar, B. (2002). Açıklamalı dilbilim terimleri sözlüğü. İstanbul: Multilingual Yabancı Dil Yayınları.

Yıldırım, A. ve Şimşek, H. (2011). Sosyal bilimlerde nitel araștırma yöntemleri. Ankara: Seçkin Yayınları. 